\title{
Remedies for Unjustifiable Dismissal under the Labour Relations Act 1987
}

\author{
Bronwyn Boon*
}

\section{Introduction}

This research note presents the results of a survey of remedies awarded in unjustifiable dismissal cases decisioned in the period 1987 to 1991 under the jurisdiction of the Labour Relations Act 1987 (LRA). The results of the survey were found to suggest that while the procedure in principle offered the possibility of adequate recompense for an unjustifiable dismissal, in practical terms it generally failed to deliver adequate means for their recovery. This conclusion supported the somewhat critical position adopted by Anderson (1988) in his discussion of the performance of the Labour Court and the remedies awarded for unjustifiable dismissals. The note will briefly present the remedies available under the LRA and the criticisms expressed by Anderson (1988) before presenting the survey results.

\section{Remedies available under the Labour Relations Act}

The LRA provided scope for comprehensive redress for an unjustifiable dismissal in the form of reinstatement, reimbursement and compensation.

Reinstatement under the LRA was deemed to be the primary remedy for an unjustifiable dismissal (s228). While the reinstatement was to be to the same position, with the same wages, privileges and obligations or to one of no less advantage to the worker (s227(a)), it was qualified by the need to be "practicable" under the circumstances of the case (s228(b)). Under this requirement to be practicable, reinstatement may have been refused due to the irretrievable breakdown of the employer-employee relationship (Szakats \& Mulgan 1990). Refusal may also have resulted due to the delay, often present, between the dismissal and the hearing (Anderson 1983). If there was significant delay, an employer was entitled to fill the vacant position and in such a case, the judge was loathe to evict the new employee from the position (Szakats \& Mulgan 1990).

Reimbursement was available for lost wages. While the court was obliged to provide a minimum of three months wages, the sum may have been increased or decreased by a number of factors. Amongst these were the effort the worker had made to mitigate the loss by gaining employment elsewhere, funds received from social welfare, and fault on the part of the worker contributing to the dismissal (s229 (3)). Department of Management, University of Otago. The author is grateful to Dr Alan Geare and Dr Ian McAndrew
for their helpful comments, and to the Industrial Relations Service of the Department of Labour for assistance with data access. 
Compensation may have been awarded for both personal upset the worker may have suffered such as humiliation, loss of dignity and injury to feelings and the loss of any benefit - either monetary or otherwise. As with reimbursement, compensation was qualified by the contributory factor.

\section{The study}

Some commentary on the nature of unjustifiable dismissal remedies awarded by the Labour Court is available in Anderson (1988). While the LRA spoke of reinstatement as the primary remedy, Anderson criticized the court for failing to treat it as such in practice. This failure Anderson described as being the result of the pragmatic approach by the court, the delays inherent in the procedure, the disruptive impact reinstatement would have had on the majority of work-places in New Zealand ar d "the attitude that reinstatement, rather than being a primary remedy, is a reward for good employees" (ibid p269). Anderson was also critical of the court's unwillingness to award full compensation, attributing this approach to the contributory fault principle, the absence of property rights over jobs, and again concern over the impact large settlements may have on employers, particularly the smaller employers. As a result, Anderson concluded:

the court's concem to be fair to both sides, together with a view that sees the grievance procedure as aimed at ensuring faimess rather than creating legal rights, seems to have led to a level of compensation that does not recognise the real economic consequences of dismissal. A worker who is found to be unjustifiably dismissed will always end up losing (1988 p270).

By way of testing the foundation for Anderson's critique, this note presents a profile of remedies awarded in a sample of unjustifiable dismissal cases under the LRA. Cases will be analyzed in terms of whether the dismissals were held to be unjustified, whether reinstatement was ordered, how much reimbursement was awarded and how much compensation was awarded.

\section{The data}

The total study sample size consisted of 597 cases. Tables 1 (a) and 1 (b) provide a breakdown of the data source:

Table 1(a) Data from the Labour Court

\begin{tabular}{||l|c|c|c|c|c||c||}
\hline & 1987 & 1988 & 1989 & 1990 & 1991 & Total \\
\hline $\begin{array}{l}\text { Labour Court } \\
\text { Published: }\end{array}$ & 11 & 65 & 49 & - & - & 125 \\
\hline $\begin{array}{l}\text { Labour Court } \\
\text { Unpublished: Auckland }\end{array}$ & - & - & 16 & 60 & 17 & 93 \\
\hline Wellington & - & - & 8 & 11 & 11 & 30 \\
\hline Christchurch & - & - & 5 & 17 & 17 & 39 \\
\hline Total Labour Court & 11 & 65 & 78 & 88 & 45 & 287 \\
\hline
\end{tabular}


Table 1(b) Data from The Mediation Service

\begin{tabular}{|l|c|c|c|c|c||}
\hline $\begin{array}{l}\text { Mediation Service: } \\
\text { 1990 only }\end{array}$ & C'tee & Chair & $\begin{array}{l}\text { Total } \\
\text { Med. } \\
\text { Sample }\end{array}$ & $\begin{array}{l}\text { Total } \\
\text { Pop. } \\
\text { Size } \\
(1990)\end{array}$ & $\begin{array}{l}\text { Sample } \\
\text { as \% of } \\
\text { Pop. }\end{array}$ \\
\hline Auckland & 58 & 77 & 135 & 597 & $23 \%$ \\
\hline Wellington & 39 & 38 & 77 & 483 & $16 \%$ \\
\hline Christchurch & 31 & 30 & 61 & 196 & $13 \%$ \\
\hline Dunedin & 31 & 6 & 37 & 116 & $32 \%$ \\
\hline Total & 159 & 151 & 310 & 1,392 & $22 \%$ \\
\hline
\end{tabular}

The Labour Court sample includes all decisions issued under the LRA in cases alleging unjustifiable dismissal between August 1987 and August 1991, exclusive of procedural decisions, such as those responding to petitions for direct hearing or for a hearing date.

The mediation service sample consists of 310 cases, being a randomly selected onehalf of the case reports held by the Department of Labour for the 1990 calender year. At the time of the study, the Department had received from Mediators case reports for approximately one-half of the personal grievance cases dealt with by the Mediation Service during 1990. Of the 310 Mediation Service cases in the study sample, 159 were decided by the Grievance Committee and 151 were decided by the Chair.

\section{Results}

The number of dismissals found to be unjustified

Tables 2 (a) and 2 (b) detail the numbers of unjustifiable dismissal claims upheld by the Labour Court and the Mediation Service respectively, in the sample cases. Overall, threequarters of the unjustifiable dismissal claims were upheld.

Table 2(a) The number of cases taken to personal grievance found to be unjustified by The Labour Court $(n=287)$

\begin{tabular}{||l|c|c|c|c|c||}
\hline The Labour Court: & 1987 & 1988 & 1989 & 1990 & 1991 \\
\hline $\begin{array}{l}\text { Total number of Dismissal } \\
\text { cases }\end{array}$ & 11 & 65 & 78 & 88 & 45 \\
\hline $\begin{array}{l}\text { Number of cases found to be } \\
\text { unjustified }\end{array}$ & $\begin{array}{c}8 \\
(73 \%)\end{array}$ & $\begin{array}{c}48 \\
(74 \%)\end{array}$ & $\begin{array}{c}57 \\
(73 \%)\end{array}$ & $\begin{array}{c}64 \\
(73 \%)\end{array}$ & $\begin{array}{c}25 \\
(54 \%)\end{array}$ \\
\hline
\end{tabular}


Table 2(b) The number of cases taken to personal grievance found to be unjustified by The Mediation Service $(n=310)$

\begin{tabular}{||l|c|c||}
\hline \hline The Mediation Service: 1990 & Committee & Chair \\
\hline Total number of Dismissal cases & 159 & 151 \\
\hline $\begin{array}{l}\text { Number of cases found to be } \\
\text { unjustified }\end{array}$ & $\begin{array}{c}159 \\
(100 \%)\end{array}$ & $\begin{array}{c}86 \\
(57 \%)\end{array}$ \\
\hline
\end{tabular}

Of the Mediation Service sample, all cases dealt with at the committee level and just over half decided by the chair were found to be unjustified. The $100 \%$ result from the committee is not surprising in view of the process behind a decision made at this stage. Under the LRA, the first step in the formal resolution of an unjustifiable dismissal dispute was the formation of a grievance committee. Composed of equal numbers from each side, the function of the Committee was to negotiate an acceptable outcome to the dispute. Resolution at this early stage implies an acceptance by both parties of some wrong-doing on behalf of both the employer and the employee. As the employer is prepared to bargain, the dismissal must be considered to be in some way unjustifiable. Without this acceptance, the dispute would be passed on to either arbitration by the Chair of the Committee, or to the Labour Court.

\section{Reinstatement}

Table 3 provides the numbers of cases where the dismissal was found to be unjustifiable and the decision-maker has ordered reinstatement as part (or whole) of the remedy.

Table 3 Cases where reinstatement is ordered $(n=447)$

\begin{tabular}{|c|c|c|c|c|c|c|c|c|}
\hline \multicolumn{6}{|c|}{ Court } & C'tee & Chair & Total \\
\hline & 1987 & 1988 & 1989 & 1990 & 1991 & 1990 & 1990 & \\
\hline $\begin{array}{l}\text { Dismissals } \\
\text { held to be } \\
\text { unjustifiable }\end{array}$ & 8 & 48 & 57 & 64 & 25 & 159 & 86 & 447 \\
\hline $\begin{array}{l}\text { Reinstate- } \\
\text { ment } \\
\text { ordered }\end{array}$ & $\begin{array}{c}2 \\
(25 \%)\end{array}$ & $\begin{array}{c}9 \\
(19 \%)\end{array}$ & $\begin{array}{l}18 \\
(31 \%)\end{array}$ & $\begin{array}{l}10 \\
(16 \%)\end{array}$ & $\begin{array}{c}3 \\
(12 \%)\end{array}$ & $\begin{array}{c}6 \\
(3 \%)\end{array}$ & $\begin{array}{c}29 \\
(19 \%)\end{array}$ & $\begin{array}{c}77 \\
(17 \%)\end{array}$ \\
\hline
\end{tabular}

The results indicate that of employees held to have been unjustifiably dismissed, less than one in five regained his or her position. Despite $100 \%$ of the Committee group cases being accepted as unjustifiable, only $3 \%$ of employees were reinstated. This result suggests that while employers were prepared to admit to some fault on their behalf (even in $95 \%$ of cases to negotiate compensation for that fault) their bargaining range usually stopped short of reinstatement. Of the total 77 employees reinstated to their former position, 40 received additional compensation while the remaining 37 did not. 


\section{Reimbursement}

Reimbursement results presented in table 4 below, indicate that less than half of the employees held to have been unjustifiably dismissed were awarded reimbursement.

Table 4 The reimbursement profile from the cases studied $(n=447)$

\begin{tabular}{||r|r|r|r|r|r||r||r||}
\hline \multicolumn{7}{|c|}{ Reimbursement } \\
\hline & 1987 & 1988 & 1989 & 1990 & 1991 & 1990 & 1990 \\
\hline & 8 & 48 & 57 & 64 & 25 & 159 & 86 \\
\hline $\begin{array}{l}\text { Dismissals } \\
\text { held to be } \\
\text { unjustifiable }\end{array}$ & 29 & 29 & 36 & 41 & 21 & 6 & 54 \\
\hline $\begin{array}{l}\text { Reimbursement } \\
\text { ordered }\end{array}$ & $25 \%)$ & $(60 \%)$ & $(63 \%)$ & $(64 \%)$ & $(84 \%)$ & $(5 \%)$ & $(98 \%)$ \\
\hline $\begin{array}{l}\text { Maximum } \\
\text { amount }\end{array}$ & 8,316 & 20,272 & 20,000 & 55,000 & 63,000 & 9,530 & 10,851 \\
\hline $\begin{array}{l}\text { Minimum } \\
\text { amount }\end{array}$ & 240 & 234 & 250 & 500 & 200 & 34 & 375 \\
\hline Average & 1,220 & 4,127 & 5,866 & 6,439 & 15,422 & 3,020 & 4,235 \\
\hline $\begin{array}{l}\text { Missing (\$) } \\
\text { values** }\end{array}$ & 0 & 4 & 12 & 11 & 7 & 2 & 30 \\
\hline
\end{tabular}

** Not all case reports provided specific monetary amounts. In some the judge ordered the issue back to the committee for negotiation. In others, due to the unavailability of information, the court deferred judgement to a later hearing.

For the total of 189 employees receiving reimbursement $(42 \%$ of the unjustified dismissal group) the average payment was approximately $\$ 5700$. The particularly small number of reimbursement payments from the Committee reflects the nature of the reporting from this group. In many, one figure was presented without differentiating between reimbursement and compensation. On such occasions, the figure was included in the compensation section. While the court generally awarded higher levels of reimbursement than the Grievance Committees or their Chair, the longer time delay between the dismissal and the resolution of the dispute at the court level was presumably a factor in this disparity.

\section{Compensation}

Table 5 completes the presentation of results in this note with a profile of the compensation awarded to the employees found to have been unjustifiably dismissed. 
Table 5 The compensation profile from the cases studied

\begin{tabular}{|c|c|c|c|c|c|c|c|}
\hline \multicolumn{8}{|c|}{ Compensation } \\
\hline & \multicolumn{5}{|c|}{ Court } & \multirow{2}{*}{$\begin{array}{l}\text { C'tee } \\
1990 \\
\end{array}$} & \multirow[t]{2}{*}{ Chair } \\
\hline & 1987 & 1988 & 1989 & 1990 & 1991 & & \\
\hline $\begin{array}{l}\text { Dismissals } \\
\text { held to be } \\
\text { unjustifiable }\end{array}$ & 8 & 48 & 57 & 64 & 25 & 159 & 86 \\
\hline $\begin{array}{l}\text { Compensation } \\
\text { ordered }\end{array}$ & $\begin{array}{r}7 \\
(87 \%) \\
\end{array}$ & $\begin{array}{r}37 \\
(77 \%) \\
\end{array}$ & $\begin{array}{r}45 \\
(79 \%) \\
\end{array}$ & $\begin{array}{r}44 \\
(69 \%) \\
\end{array}$ & $\begin{array}{r}22 \\
(88 \%) \\
\end{array}$ & $\begin{array}{r}151 \\
(95 \%) \\
\end{array}$ & $\begin{array}{r}61 \\
(71 \%) \\
\end{array}$ \\
\hline $\begin{array}{l}\text { Maximum } \\
\text { amount }\end{array}$ & 4,000 & 16,000 & 200,000 & 52,200 & 154,000 & 75,235 & 48,500 \\
\hline $\begin{array}{l}\text { Minimum } \\
\text { amount }\end{array}$ & 282 & 280 & 198 & 40 & 150 & 207 & 200 \\
\hline Average & 1,658 & 2,615 & 11,351 & 8,231 & 24,124 & 4,466 & 4,496 \\
\hline
\end{tabular}

Of the 447 employees deemed to have been unjustifiably dismissed, $367(82 \%)$ had some payment of compensation in their remedy packages. The overall average of this payment was in the area of $\$ 8000$. Some very high amounts awarded by the Court in 1989 and 1991, inflate the court average relative to the averages of the committee and the chair. In addition this produced an uneven profile with respect to a general increase over time in the amount of compensation awarded. Of those employees receiving compensation, 40 were also reinstated. For these people, the group average payment was in the range of $\$ 3700$. The remaining 327 not reinstated were payed an average compensation amount of $\$ 7,459$.

\section{Conclusion}

The results presented in this note reveal that generally three-quarters of the sample dismissals challenged under the personal grievance procedure of the LRA were found to be unjustifiable. Of those employees held to have been unjustifiably dismissed, only a quarter regained their jobs. Just over a half were awarded some amount of reimbursement payment and around three-quarters had compensation included in the settlement. While payments have at times been as large as $\$ 63,000$ for reimbursement and $\$ 200,000$ for compensation, figures of this magnitude were not usual. At the other end of the scale, the amounts reported were as low as $\$ 34$ reimbursement and $\$ 40$ compensation. These results presented an overall average payment of $\$ 5,761$ for reimbursement and $\$ 8,134$ for compensation.

It is acknowledged that a dismissal may be found to be unjustifiable due to a variety of reasons. The employer may have committed gross violations of fair procedure or at the other end of the spectrum, relatively minor technical discrepancies. In addition there may have been little or no substantive reason for the dismissal. While this variation exists in unjustified dismissal decisions, it is assumed that following careful consideration of the facts 


\section{Remedies for Unjustifiable Dismissal 107}

of the case, the decision-maker has come to the final conclusion that the dismissal should not have taken place. As such, remedy for an unjustifiable dismissal is just what it implies - a form of redress for a wrong doing or more specifically, for the unjustified loss of a job.

Assessing the dollar value of a job, including not only the specific loss of wages but also the loss of intangible value, is admittedly difficult in the absence of prescriptive criteria. However, given the dependence of most people in our society on their job, as a means not only for their survival but also their well-being, it is reasonable to suggest that $\$ 7,459$ is a poor price to be paid for an unjustifiably lost job. Particularly as five out of six workers, while found to be unjustifiably dismissed, are left without a job. As such the findings of this study can only support the conclusions formed by Anderson (1988). While the New Zealand personal grievance procedure dealing with unjustifiable dismissals under the LRA (and essentially that under the Employment Contracts Act 1991) may provide in principle an adequate form of redress, in practical terms it is likely to offer little to the aggrieved worker.

\section{References}

Anderson, Gordon (1983), Procedural Fairness and Unjustifiable Dismissal, New Zealand Journal of Industrial Relations 8(1): 1-10.

Anderson, Gordon (1988), The Origins and Development of the Personal Grievance Jurisdiction in New Zealand, New Zealand Journal of Industrial Relations 13(3): 257-275.

Szakats, A. and Mulgan, M.A. with contributions by Vranken, M. (1990), Dismissal and Redundancy Procedures, 2nd edition, Butterworths of New Zealand.

The Labour Relations Act 1987. 